Volume 16, Number 1, Juni 2019

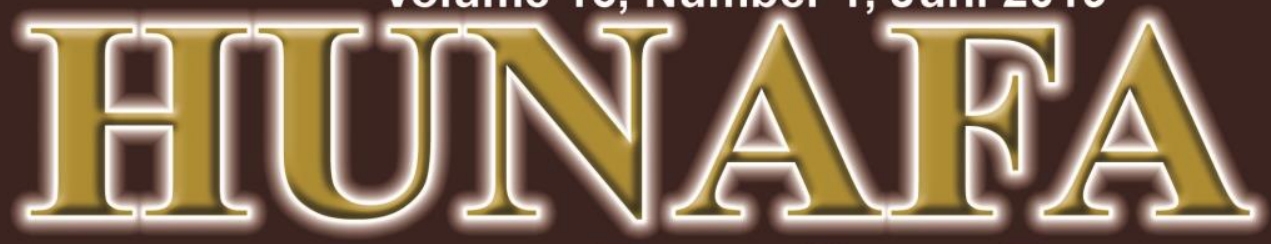

Jurimal Stradial Islamilka

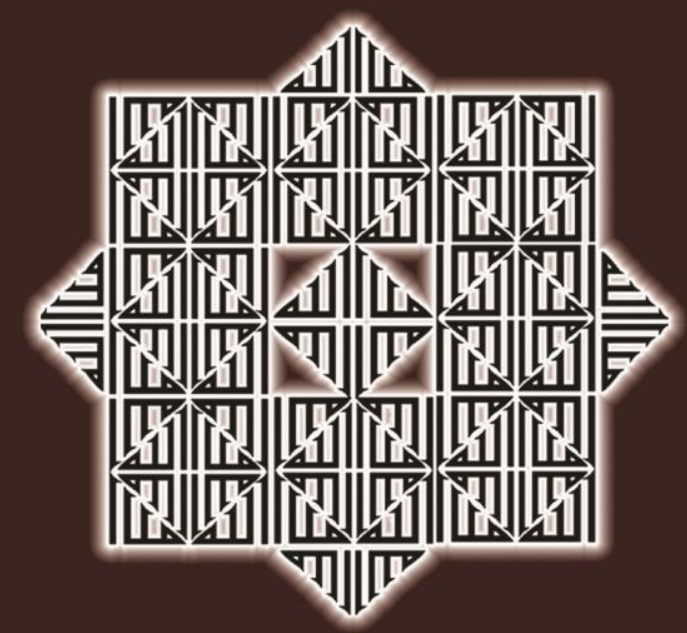

ALKHAIRAAT POLITICAL CHARISMA Syamsuri

IRAN REVOLUTION, ECONOMIC STRUGGLE AND INDEPENDENCE UNDER PRESSURE Meirizon Alizar Ali

\author{
MARKETING PERFORMANCE DETERMINANT \\ OF HALAL PRODUCTS IN INDONESIA \\ Confirmatory Factor Analysis Approach \\ Aan Nasrullah
}

State lnstitute for lsiamic Studies (ILAIN) Palu central Sulawesi

\begin{tabular}{|c|c|c|c|c|c|}
\hline $\begin{array}{c}\text { HUNAFA } \\
\text { JSI }\end{array}$ & $\begin{array}{c}\text { Volume } \\
16\end{array}$ & $\begin{array}{c}\text { Number } \\
1\end{array}$ & $\begin{array}{c}\text { Page } \\
1-153\end{array}$ & $\begin{array}{c}\text { Palu } \\
\text { Juni } 2019\end{array}$ & $\begin{array}{c}\text { ISSN } \\
\text { 141-125X }\end{array}$ \\
\hline
\end{tabular}




\section{HUNAFA}

Jurnal Studia Islamika

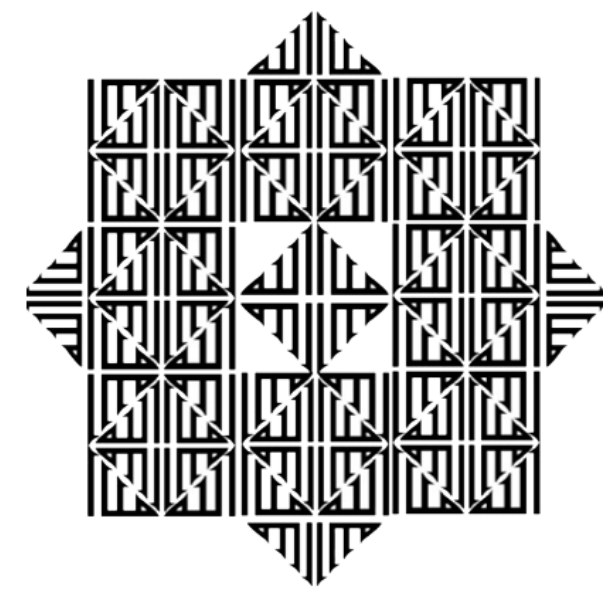

Published by:

State Islamic Institute (IAIN) Palu

Central Sulawesi 


\section{HUNAFA}

Jurnal Studia Islamika

HUNAFA: Jurnal Studia Islamika is an Islamic studies journal dedicated to publishing scholarly articles on all aspects of Islam and the Muslim peoples and religious studies. Available in print and online and published twice a year, the journal aims to become one of the leading platforms in Indonesia for new findings and discussions of all fields of Islamic studies. This journal invites scholars, researchers, and students to contribute the result of their studies and researches in the areas related to Islam and Muslim society which covers textual and fieldwork investigation with various perspectives of law, education, quranic studies, economiy, philosophy, mysticism, theology, sociology, and others.

\section{CAll rights reserved}

No part of this publication may be reproduced in any form without written permission from HUNAFA, to whom all requests to reproduce copyright material should be directed. HUNAFA grants authorization for individuals to photocopy copyright material for private research use. This authorization does not extend to any other kind of copying, by any means, in any form, and for any purposes other than private research.

\section{Open Acces Journal Information}

The journal provides immediate open access to its content on the principle that making research freely available to the public supports a greater global exchange of knowledge. The journal offers full access contents at http://jurnalhunafa.org.

\section{Printed Journal Subscription Information}

Institution Rp 100.000,00 /issue; Rp 1.100.000,00/year

Individual: Rp. 60.000,00/issue; Rp. 600.000,00/year

Outside Indonesia (individual or institution) \$60/month; \$600/year

For detail information of printed journal subscription, feel free to contact the journal manager at hunafajournal@gmail.com.

\section{Mailing Address}

HUNAFA: Jurnals Studia Islamika

Lembaga Penelitian dan Pengabdian Masyarakat (LP2M) IAIN Palu 
Jl. Diponegoro No. 23 Palu, Sulawesi Tengah 94221 Indonesia

Phone: +62-451-460798; Fax: +62-451-460165

E-mail: jurnalhunafa@yahoo.com; hunafajournal@gmail.com

Website: www.jurnalhunafa.org

HUNAFA

Jurnal Studia Islamika

\section{EDITOR-IN-CHIEF}

Nurdin, Institut Agama Islam Negeri Palu, Indonesia

\section{EDITORIAL BOARD}

Sagaf S. Pettalongi, Institut Agama Islam Negeri Palu, Indonesia

Rusli, Institut Agama Islam Negeri Palu, Indonesia

Tulus Suryanto, Universitas Islam Negeri Raden Intan Lampung, Indonesia

Ade Yeti Nuryantini, Universitas Islam Negeri Sunan Gunung Djati, Indonesia

Toto Suharto, Institut Agama Islam Negeri Sukoharjo, Indonesia

Reza Fahmi, Universitas Islam Negeri Imam Bonjol Padang, Indonesia

Mohamad Abdalla, University of South Australia, Australia

Cucuk Wawan Budiyanto, Universitas Sebelas Maret, Indonesia

Kevin W. Fogg, University of Oxford, United Kingdom

Al Makin, Universitas Islam Negeri Sunan Kalijaga Yogyakarta, Indonesia

Miftachul Huda, Universiti Teknologi Malaysia, Malaysia

Hendri Tanjung, Ibn Khaldun University Bogor, Indonesia

Muhammed Modassir Ali, Hamad bin Khalifa Universty, Qatar

Hamid Fahmi Zarkasyi, Universitas Darussalam Gontor, Indonesia 


\section{MANAGING EDITOR}

Mohammad Nur Ahsan, Institut Agama Islam Negeri Palu, Indonesia

\section{COVER DESIGN}

Lukman Latif 


\section{HUNAFA \\ Jurnal Studia Islamika}

\section{Contents}

Editorial

vi-vii

AL-KHAIRAAT POLITICAL KHARISMA

$1-18$

Syamsuri

BANGRENG AS A MEANS OF SPREADING ISLAM

Melyan Sofian, Cece Sobarna, Reiza D. Deinaputra, Deni Hermawan

FOREIGN LANGUAGE TEACHING AND INFORMATION COMMUNICATION TECHNOLOGY: IS THERE OPPORTUNITY FOR QURANIC LANGUAGE TEACHERS?

Nuril Mufidah, Abduganiy Abimbola Abdussalam, Aliy Abdulwahid Adebisi

IRAN REVOLUTION, ECONOMIC STRUGGLE AND INDEPENDENCE UNDER THE PRESSURE

Meirozon AlizarAli 
Umi Salamah

MAHRAM IMPLICATIONS IN WOMEN'S TRAVEL

$88-110$

Maulidah Tri Utami

MARKETING PERFORMANCE DETERMINANT

OF HALAL PRODUCTS IN INDONESIA:

Confirmatory Factor Analysis Approach

Aan Nasrullah

RELATIONS BETWEEN MOSQUE AND

$142-153$

SOCIAL HISTORY OF ISLAMIC EDUCATION

Anna Triayudha, Rateh Ninik Pramitasary, Hermansyah Akbar Anas, Choirul Mahfud 


\section{Editorial Preface}

Nurdin Nurdin, Institut Agama Islam Negeri (IAIN) Palu

This issue (Vol. 16 issues 1) of Hunafa: Jurnal Studia Islamika offers eight articles covering topics of Islamic studies. Various issues relating to Islamic studies are presented interestingly to contribute to the body of knowledge and practices. Academia and practitioners in Islamic studies may gain insight from reading these articles.

The first article is titled "Al-Khairaat Political Kharisma" by Syamsuri Syamsuri from Department of Dakwah, Faculty of Ushuluddin, Adab, and Dakwah, Institut Agama Islam Negeri Palu. This paper discusses the roles of Al-Khairaat in politics arena within local and national level. Several political parties have come to the Alkhairaat organization to recruit political cadres in the face of general election events.Alkahiraat's political charisma in the frame of political communication includes the participation, consolidation, and partnership of Alkhairaat politicians who spread in various political parties to win the election contestation.

The second article in the issue is titled "Bangreng as a Means of Spreading Islam" by Maylan Sofian, Cece Sobarna, Reiza D. Dienaputra, and Deni Hermawan from STKIP Sebelas April Sumedang. This paper describe Bangreng culture which was originally an example used by the Sumedang community as a medium to express gratitude for everything that Allah SWT gave to humans. But the function of art as a ritual began to shift into art as entertainment. This Bangreng art is an art that is very interesting to study because there are only a few different functions. This change does not change the name of the show. With this description, it needs to be isolated, that is, the community does not lose identity. The aim is that the public knows the function of the nation in the spread of Islam.

The third article is titled "Determinants of Halal Product Marketing Performance In Indonesia: Confirmatory Factor Analysis Approach" by Aan Nasrullah. This paper discussed the five variables that contribute to halal product marketing which are product competition, HR marketing performance, infrastructure, amount of distribution cost, and market competition.

The fourth article is titled "Foreign Language Teaching and Information Communication Technology: Is There Opportunity for Quranic Language Teachers?"by Nuril Mufidah, Abdulganiy Abimbola Abdussalam, Aliy Abdulwahid Adebisi from UIN Maulana Malik Ibrahim Malang and University of Ilorin, Ilorin, Nigeria. The article discuses the use of ICT in learning of Arabic. The subjects of the study were students of Arabic Language Education at UIN Maulana Malik Ibrahim Malang Indonesia 2018 academic year and students and Department of Arabic, Faculty of Arts University of Ilorin, Nigeria. The findings of the research are that ICT if adequately harnessed and utilized will go a long way in enhancing the quality of teaching of Arabic, as it was established to teaching other languages of the world.

The fifth article is by Meirizon Alizar Ali dari UIN Imam Bonjol. The article is titled "Iran Revolution, Economic Struggle and Independence under the Pressure" The article discusses 
Iran economy situation after experiencing various kinds of changes in economic policy and facing various kinds of situations Iran succeeded in developing the economy without changing the basics of Islamic shari'ah principles and revolution.

The sixth article is titled "Kaisa Method in Intelligence Multiple Perspective" by Umi Salamah from PGMI, STAI Ma'had 'Aly Al-Hikam, Malang. The article analyzed memorizing the Qur'an using the Kaisa method in the perspective of multiple intelligence. The Kaisa method is a way of memorizing the Qur'an which is oriented to memorization and understanding of the verses of the Qur'an along with their meanings through movements or kinesthetic which are adapted to the meaning of each verse so as to make it easy to understand and remember every verse of the Qur'an given.

The seventh article is titled "Mahram Implications in Women's Travel" by Maulidah Tri Utami from Faculty UshuluddinAdab and Humaniora, IAIN Salatiga. The article discusses mahram as well as a culture of the manner in which a woman is going out of her home or is drawn. From the various resources available this article determine when a woman can compete without mahram.that is how Islam respects and cares for a woman so much that it also notices when a woman is about to travel. Not just one woman, but all Muslim have a rule if a Muslim is to compete for a long time. So, when to reply a Muslim must meet or finish what he needs before taking a sauna.

The last article is titled "Relations Between Mosque And Social History of Islamic Education" by Choirul Mahfud Anna Triayudha, Rateh Ninik Pramitasary, and Hermansyah Akbar Anas from Institut Teknologi Sepuluh Nopember, Surabaya and Pascasarjana Universitas Muhammadiyah Sidoarjo. The article describe the early period of Islamic education, the Prophet provided exemplary by building and empowering mosques. The example of the Prophet continued with the Caliphs afterwards until the present era. The mosque was built by the Prophet from the Al Haram mosque located in Makkah, Quba Mosque located in Quba, Nabawi mosque located in Medina and so on. The role and function of the mosque at that time was as a place of prayer, a place of prayer, a place for discussion or deliberation, a meeting place to develop a war strategy and others related to the problems and needs of Muslims. From time to time, the role or function of the mosque has changed slightly. In essence, mosques are currently influencing the development of the social history of Islamic education in Indonesia.

I hope the articles presented in this issue add further empirical evidence to the growing body of research that examines various fields from Islam perspectives. The articles could trigger other research to study other field of study with Islam perspectives Islamic institutions in Indonesia.

Nurdin Nurdin

Editor-in-Chief

HUNAFA: Jurnal Studia Islamika

XVI, 1 
Jurnal Hunafa: Studia Islamika, Volume 16, Number 1, p. 111-141.

E-ISSN: 2355-7710

P-ISSN: $1411-125 \mathrm{X}$

\title{
MARKETING PERFORMANCE DETERMINANT \\ OF HALAL PRODUCTS IN INDONESIA
}

Confirmatory Factor Analysis Approach

\author{
Aan Nasrullah ${ }^{1}$ \\ ${ }^{1}$ Economy Sharia, STAI Miftahul ‘Ula, Nganjuk, aan.aljalil@ymail.com
}

\begin{abstract}
The aims of this study are (1) To find out and analyze the factors that contribute greatly to the performance of marketing halal products, (2) To find out and analyze marketing performance factors that have the most dominant multiplier effect on the development of halal products in Indonesia. The data analysis technique used is Confirmatory Factor Analysis (CFA). The results of this study show that based on the results of the analysis with the CFA method there are five independent variables that have a contribution to the dependent variable. First the Product Competition Level variable with a correlation value of 0.920 . Second, HR Marketing Performance variable which has a correlation value of 0.895 . Third, Infrastructure variables with a correlation value of 0.873. Fourth, Amount of Distribution Cost with a correlation value of 0.741 , as well as the five variables X3, namely Market Competition Level variables with a correlation value of 0.572 . Correlation value-of the five variables shows a strong relationship between the five independent variables with the performance variable of marketing halal products. From a number of marketing performance factors formed through literature review and after analysis using the CFA method, product competition variables are variables that have a correlation value of 0.920 . The matrix component value shows a strong correlation between product competition variables and the performance of halal product marketing. The correlation value is greater than the other four independent variables.
\end{abstract}

Keywords: marketing performance, halal products, confirmatory factor analysis

Abstrak. Tujuan penelitian ini(1) Untuk menganalisis faktor-faktor yang berkontribusi terhadap kinerja pemasaran produk halal, (2) 
Untuk menganalisis faktor-faktor kinerja pemasaran yang memiliki efek multiplier dominan terhadap pengembangan produk halal di Indonesia.teknik analisis data yang digunakan adalah Analisis Faktor Konfirmatori (CFA) suatu teknik analisis faktor di mana secara apriori berdasarkan teori dan konsep yang sudah diketahui dipahami atau ditentukan sebelumnya. Berdasarkan hasil analisa dengan metode CFA terdapat lima variabel independen yang memiliki kontribusi terhadapvariabel kinerja pemasaran produk halal. Pertama, variabel Tingkat Kompetisi Produk dengan nilai korelasi sebesar 0,920. Kedua, variabel Kinerja SDM Marketing yang memiliki nilai korelasi sebesar 0,895. Ketiga, variabel varibel Infrastruktur dengan nilai korelasi 0,873.Keempat,variabel Besaran Biaya Distribusi dengan nilai korelasi sebesar 0,741, dan kelima, varibel Tingkat Kompetisi Pasar dengan nilai korelasi sebesar 0,572. Dari beberapa faktor kinerja pemasaran yang dibentuk melalui kajian pustaka dan setelah dilakukan analisa dengan metode CFA. Variabel kompetisi produk adalah variabel yang memiliki nilai korelasi sebesar 0,920 . Nilai componet matrix ini menunjukkan adanya korelasi yang kuat antara variabel kompetisi produk dengan kinerja pemasaran produk halal. Nilai korelasi tersebut lebih besar dari keempat variabel independen lainnya.

Kata Kunci: kinerja pemasaran, produk halal, confirmatory factor analysis

DOI: $10.24239 /$ jsi.v16i1.538.111-141

\section{Introduction}

The last few years the Indonesian government has actively developed the Islamic economy, which is marked by the government's efforts to drive the growth of the domestic sharia industry, starting from the financial sector and continuing to develop the real sector. So it is not excessive if on September $30^{\text {th }}, 2016$, the President of the Republic of Indonesia (RI), Joko Widodo received the 2016 Global Islamic Finance Leadership Award from the Global Islamic Finance Awards (GIFA) for his role in 
promoting Islamic finance in Indonesia ${ }^{1}$.The_development of the real sector in this case is the halal product industry which has become a special concern by the government, this can be seen from the government's efforts in issuing a legal framework for the development of the domestic halal product industry, one of which is Law Number 33 Year 2014 regarding Halal Product Guarantee, and several other government regulations. The law covers, protection, justice, legal certainty, accountability and transparency, effectiveness and efficiency as well as professionalism.

Government efforts in developing halal products in the country, more or less influenced by the large demand for halal products, both domestic and foreign markets. The demand of halal food products in Asia, such as in Japan, is also increased ${ }^{2}$, as well as other halal products, for example, the demand for cosmetic products among Muslim women has increased significantly. In 2014 the world's demand for halal cosmetic products was USD 54 billion and is estimated to increase to US $\$ 80$ billion by $2020 .^{3}$ Likewise, in Europe, for example in France the rapid growth of the Muslim population linearly influences the growth in demand for halal products. This can be seen from the demand for halal products on the European market which has increased by $15 \%$ per year since 2003, which at that time reached 15 billion Euros. ${ }^{4}$

Likewise the halal product market in the country, also experienced significant demand. Moreover, at present the sharia-based industry including halal products is experiencing rapid development amid the increasing religious trends of Indonesian society. As a result, demand for halal products will also increase in the domestic

\footnotetext{
${ }^{1}$ OJK (Otoritas Jasa Keuangan), Roadmap Pengembangan Keuangan Syariah Indonesia 2017-2019, 4

${ }^{2}$ Kementerian Perdagangan RI. Market Intelligence: Produk Makanan Halal, Kerajinan dan Furnitur Indonesia di Pasar Jepang, (Tokyo: Atase Perdagangan, 2015). 9

${ }^{3}$ Adilah Ariffin. Faktor-faktor yang Mempengaruhi Permintaan Produk Kosmetik Halal. (Prosiding Seminar Kebangsaan Tamadun \& Warisan Islam (TAWIS). 2016). 18-30.

${ }^{4}$ Warta Ekspor Peluang Bisnis Produk Halal di Perancis Besar Berkat Pertumbuhan Penduduk Muslim Edisi: Ditjen PEN/MJL/004/4/2013. April 2013
} 
market in the future. ${ }^{5}$ Indonesia is a potential market for sharia economic growth. At present the condition of the Indonesian economy is considered good. Indonesia's Gross Domestic Product (GDP) is projected to enter the world's top five in the next few years. Natural Resources in Indonesia is still very potential to be developed. The population of Indonesia, which is around 150 million and around 87 percent, is Muslim, as seen from the income in general, the Indonesian Muslim community is in the middle class, where this middle class has increased from time to time. ${ }^{6}$

The halal product industry has become the center of attention in the global market and is claimed to be one of the fastest growing markets currently expected to grow at a rate of 7 percent per year with an estimated market volume of US \$580 billion per year, said that halal products are no longer limited to country demographics and are identified by national or ethnic empirical lines. One of the reasons is the application of halal certification has been felt differently in every country. The Muslim community in general considers that there is nothing more important than the halal label, because the halal label is one way to judge that the product is in accordance with Islamic teachings.

But amidst the huge potential of the halal product industry, both in national and international markets, the development of halal products in the country is still experiencing many problems. In general, the problem of developing the halal product industry in Indonesia consists of two factors, internal and external factors. Internal factors are market access and marketing activities, access to banking capital, governance and management, quality of human resources. External factors are competitive competition in the halal product market, because businesses in the

${ }^{5}$ Ali Rama, "Potensi Pasar Produk Halal Dunia," Ali Rama, 2014.

${ }^{6}$ Ma'ruf Amin, at UIN Maulana Malik Ibrahim Malang, Solusi Hukum Islam (Makharij Fighiyah) Sebagai Pendorong Arus Baru Ekonomi Syariah di Indonesia (Kontribusi Fatwa DSN-MUI dalam Peraturan Perundang-undangan RI). Scientific Oration. 2017

${ }^{7}$ Ahmad Rafiki, "Determinants on the Obtainment of Halal Certification Among Small Firms", World Applied Sciences Journal, 32 No. 1, (2014), 47-55. 
halal product market are not only Muslim countries, but also developed countries are also oriented to the development of halal products. ${ }^{8}$ Another problem is the small number of companies that meet the terms and conditions of halal certification ${ }^{9}$, as one of the stages in issuing halal labeled products.

In this context, many things are interrelated and interact with each other so that the development of halal products in Indonesia, especially with regard to marketing of halal products, is a channel from halal product providers (companies) to users (consumers). All of these are interrelated and holistic socio-economic realities, so that in its study the issue of developing halal product marketing cannot be uprooted from its social roots and cannot be framed with just one discipline such as economics, but studies from other fields of study are needed.

Therefore this study will examine the factors that influence the marketing performance of halal products, the factors that researchers use in this study are based on some previous research and some literature studies that are directly related to the research theme. In order to have a comprehensive factors, this research approach using Confirmatory Factor Analysis (CFA), the researchers formulated in the title Marketing Performance Determinant of Halal Products in Indonesia (Approach Confirmatory Factor Analysis Approach)

\section{The Concept of Economic Rationality}

In the terminology building, the concept of economic rationality arises, anyone who can seek his welfare (material wealth) by making the right choices for himself, with the principle of not letting him not get the choice because of limited availability,

8 Rahmi Rahwati, Perkembangan dan Outlook Industri Halal, Sharia Economic Outlook 2014 Masyarakat Ekonomi Syariah (MES), (2014)

${ }^{9}$ Muhammad Nusron, et.al., "Kebijakan Produk Halal dengan Simulasi Sistem Dinamik Untuk Meningkatkan Jumlah Produk bersertifikat Halal." In National Seminar Proceeding Teknologi Industri III (2015). 
then the person is considered to take action rational. ${ }^{10}$ In a more specific scope, a consumer is considered rational if he chooses a product that provides a high level of slough and vice versa, in this case rationality is determined from the level of consumer satisfaction in consuming the product.

If the behavior of an economic agent is considered rational, if he gets high satisfaction or material benefits in his economic activities. Problems in Rationality Enforcement The concept of rationality as measured by self-interest and visible things invites many problems, and contradicts the principles of Islamic economics. Imam Al-Ghazali has contributed greatly to the development and thinking in the Islamic world, one of which is an extraordinary concept in Islamic economics, namely the concept of the function of social welfare (maslahah), according to him the welfare (maslahah) of the community depends on the search and maintenance five basic goals: (1) religion, (2) life, (3) family or ancestry, (4) wealth, (5) intellect or reason. ${ }^{11}$ In other words, the parameters of the rationality of economic behavior are based on the high satisfaction received for the perpetrators themselves in these economic activities. In this case the consumer will choose a product that is considered, can provide satisfaction, in terms of compliance with religious demands and demands for product quality.

\section{Marketing Performance}

Marketing performance is a concept to measure a company's achievements in the market for a product. Every company has an interest in knowing its performance as a mirror of the success of its business in business competition..$^{12}$ Marketing performance is one to be achieved by the company in streamlining the company,

\footnotetext{
${ }^{10}$ Dede Nurohman. "Konsep Self Interest dan Maslahah Dalam Rasionalitas Ekonomi Islam." Islamica: Jurnal Studi Keislaman. 5, No. 1, (2010). 101

${ }^{11}$ Karim, A. Adiwarman. Ekonomi Mikro Islam, Edisi Ketiga. (Jakarta: PT Raja Grafindo Persada. 2010) 61-62

${ }^{12}$ Mudiantono and Nur Khamidah, "Pengaruh Diversifikasi Produk Terhadap Kinerja Pemasaran Pada Pt Bank Mandiri (Persero) Tbk Kanwil X Makassar", MINDS: Jurnal Manajemen dan Insprirasi, 3, No. 1. (2016).
} 
increase market share, and profitability. Some experts also claim that innovation in organizations is said to be successful if it can produce superior performance, which results from a commitment to total customer satisfaction that can be caused by continuous innovation. The desire to create superior value for consumers to create a competitive advantage that will continue to encourage companies to build innovations that affect performance. ${ }^{13}$ By adapting the research of Droge, et al and Pelham and Wilson's statement above, the indicators of marketing performance variables in this study are customer growth, sales growth, and market share.

\section{Marketing Performance Factors}

Marketing performance is defined as the level of performance measurement businesses include sales volume, number of customers, profits and sales growth. ${ }^{14}$ Companies that successfully "control" the market are those that always balance the two orientations (customer orientation and competitor orientation) well. By paying attention to both of these orientations will result in better marketing performance. ${ }^{15}$ From several theoretical studies and several research results, several factors can determine marketing performance, including: HR Marketing Performance, Second, Product Competition Level, Third, Market Competition Level, Fourth, Amount of Distribution Cost, and Fifth, Infrastructure.

\section{Halal Product Development Model}

Since 2009 the halal product development model in Indonesia has used triple helix, which requires synergy and partnership between three main actors: government, private, and intellectual (a team of experts from academia and the

${ }^{13} \mathrm{Ibid}$

${ }^{14}$ Mudiantono and Khamidah Nur."Analisis Pengaruh Faktor Lingkungan Terhadap Inovasi Produk dan Kreativitas Strategi Pemasaran Dalam Meningkatkan Kinerja Pemasaran (Studi Pada Perusahaan Kerajinan Keramik di Sentra Kasongan Kabupaten Bantul Yogyakarta)", Jurnal Bisnis dan Ekonomi, 12, No. 1, (2005).

15 Endang Sutrasmawati. "Pengaruh Kompetisi Produk Dalam Meningkatkan Kinerja Pemasaran Melalui Competitive Advantage." Jurnal Bisnis dan Ekonomi (JBE), 15, No.2, (2008). 
public). ${ }^{16}$ The halal product development model in Indonesia can be shown as shown in Figure 2.1 the Triple Helix. Figure 2.1 The Triple Helix shows how the design of national halal product development, like a sturdy building, the halal product development model is supported by important pillars such as financial, financial institutions, resources, institutions, technology, and industry. Then the shelter, is the government, businesses (business people), and academics. While the main foundation is human resources (people). Human resources become the main foundation in the development of halal products, because they have intelligence, so that they will produce a new industry. Human capital is the most valuable asset in a company, especially its intellectual power.

Figure 2.1 Halal Product Development Model with The Triple Helix

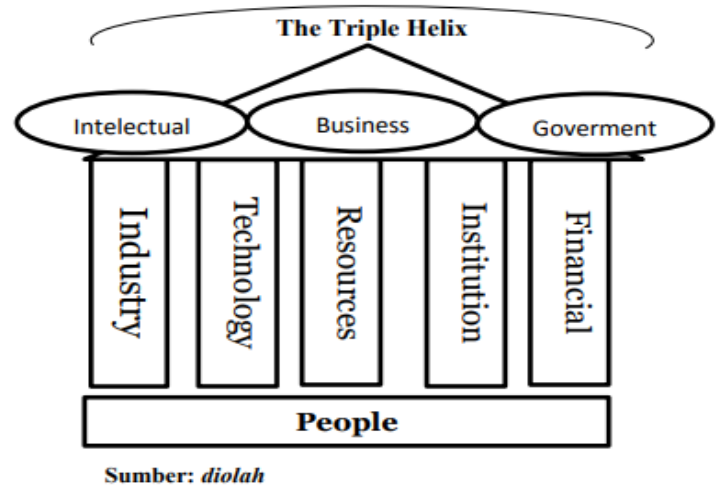

In the model of The Triple Helix, there are three main actors in the development of national halal products, namely (i) government: the function of regulation and policy development of creative economy, (ii) businesses: the function of business implementation and expansion of the market, (iii) academics: function "Knowledge" for the analysis of developments and findings in the creative economy. In response to the development progress and the demands of global competition in improving

${ }^{16}$ Syah Pahlevi and Andreas. At Unesa, Gagasan Tentang Pengembangan Ekonomi Kreatif Nasional (Studi Pada Potensi, Peluang Dan Tantangan Ekonomi Kreatif Di Kota Malang). Seminar Nasional Seni dan Desain: "Membangun Tradisi Inovasi Melalui Riset Berbasis Praktik Seni dan Desain" 2017. 
national halal products, it takes the role of other actors, as stakeholders of halal industry, the community of halal products, media and investors. So the The Triple Helix model developed into Hexa-Helix. ${ }^{17}$ As for the functions of these actors, among others, the creative community functions as an activator of creative activities that can be transformed into the concept of creative entrepreneurship, the media has a publicity and positive image function as well as the marketing of creative industry products, and investors have the function of strengthening capital for the development of pioneering new creative industry. Hexa-Helix collaboration between government, private, intellectual, creative community, the media and investors need to be applied at this time to create a healthy atmosphere in the creative industries, so that in a relatively short period of national halal products into the sectors will likely to boost export competitiveness of Indonesian products in global market in addition to impacting the national economy.

\section{Study of Confirmatory Factor Analysis Methods}

Confirmatory factor analysis Confirmatory Factor Analysis (CFA) is a statistical method used to describe the variability between the variables that potentially can be grouped into a number of groups called the factor, confirmatory factor analysis can also be used to test the validity and reliability of items questions made by the researcher Each item question will be known how many loading factors are and whether the items are suitable are grouped into the same latent variable. Confirmatory factor analysis will match the indicator model to the latent model of a latent model. ${ }^{18}$ Therefore, confirmatory factor analysis is usually used first before analyzing the structural model (Structural Equation Modeling). Its ability to produce scores for latent variables makes confirmatory factor analysis widely used to assist regression analysis with several indicators. For example, in the variable expenditure

\footnotetext{
${ }^{17}$ Ibid, 189

${ }^{18}$ Singgih Santoso, Seri Solusi Bisnis Berbasis TI: Menggunakan SPSS untuk Statistik Multivariat. (Jakarta: Elex Media Komputindo, 2006), 71
} 
or consumption, we are faced with more than one indicator. How to reduce these various variables without reducing existing information, then confirm the factor analysis of the solution.

Confirmatory factor analysis has similarities with several other statistical analysis techniques include Principal Component Analysis, Cluster Analysis, and regression analysis. Compared with Principal Component analysis, confirmatory factor analysis has similarities in terms of reducing the set of indicator items / questions to several groups / factors. The difference between the two lies in the analysis of the main component is descriptive analysis, the outcome is only in the form of scores from several groups without confirmation.

Confirmatory factor analysis is inferential statistics, which confirm whether the group formed in conformity with the latent variable or not. ${ }^{19}$ Further explains the gap / error between the two. Confirmatory factor analysis compared to cluster analysis has similarities in terms of grouping many observations into several clusters / groups of observations. The difference being grouped is the research subject / unit of analysis / respondent. Question / indicator / variable. Confirmatory factor analysis compared to regression analysis has similarities in terms of the use of linear equation models. Both use the function of linear equations to explain the relationship between indicators / questions / variables. The difference is in the number of models. Factor analysis will produce several models depending on the number of factors formed. While confirmatory factor analysis will only produce one model which will be tested for eligibility.

\section{Data Analysis Methods and Techniques}

Research Types and Approaches

\footnotetext{
${ }^{19}$ M Mushonnif Efendi and Jerry Dwi Trijoyo Purnomo, "Analisis Faktor Konfirmatori untuk Mengetahui Kesadaran Berlalu Lintas Pengendara Sepeda Motor di Surabaya Timur." Jurnal Sains dan Seni ITS, 1, No. 1, (2012).
} 
This study uses the positivism paradigm with a descriptive quantitative approach, because the research problem is clear and the researcher wants to obtain broader and real information. This type of research can be classified as explanatory research, namely research to examine the relationship between variables that have been determined. ${ }^{20}$ Quantitative research is a research method used to examine a particular population or sample in order to test a predetermined hypothesis. It is called quantitative because research data relates to numbers and analysis using statistics. ${ }^{21} \mathrm{~A}$ descriptive quantitative approach is used in this study to find out and analyze the factors that contribute greatly to the marketing performance of halal products in Indonesia.

Data Sources and Types

The type of data in this study are primary and secondary data. Primary data obtained from respondents who had been predetermined. While the secondary data obtained by researchers from the subject of this research. ${ }^{22}$ To obtain secondary data, researchers study and understand data or material obtained from various literatures, as well as noting theories obtained from books, journals, magazines, articles, or scientific works related to the discussion of this research. ${ }^{23}$ Secondary data also obtained from scientific publications and other government agencies, such as the Ministry of Industry, BPS or other scientific publications that can support the research.

Population and Research Samples

Population is the region of generalization which consists of object / subject that has qualities and specific characteristics set by researchers for study and

${ }^{20}$ Suharsini Arikunto. Prosedur Penelitian Suatu Pendekatan Praktek. (Jakarta: Rineka., 2007), 45

${ }^{21}$ Sugiyono, Metode Penelitian Kuantitatif, Kualitatif Dan R\&D, (Bandung: Alfabeta, 2014), 13.

${ }^{22}$ Ibid, 91.

${ }^{23}$ Sumadi Suryabrata, Metode Penelitian. (Jakarta: Rajawali, 1987), 94. 
then in the drop conclusion. ${ }^{24}$ While $s$ sample is part of the number and characteristics possessed by the population. ${ }^{25}$ The sampling technique used in this study is purposive sampling, which is determining the sample with certain considerations.$^{26}$ The number of samples in this study were 75 respondents who came from business actors of halal products that have been running for 10 years in the East Java region.

\section{Research Variable}

The variables in this study consisted of independent and dependent variables. The independent variable is a variable that causes the emergence or change of the dependent variable, or what is often referred to as a stimulus variable. ${ }^{27}$ Where the independent variables studied are as follows: $\mathrm{X}_{1}$ (HR Marketing Performance), $\mathrm{X}_{2}$ (Product Competition Level), $\mathrm{X}_{3}$ (Market Competition Level), $\mathrm{X}_{4}$ (Distribution Cost) and $\mathrm{X}_{5}$ (Infrastructure). Whereas the dependent variable which is the variable that influences or is the result, because a number of independent variables, in this study the dependent variable $\mathrm{Y}$ is the Marketing Performance of Halal Products.

Validity and Reliability Test

Validity test is used to measure the validity of a questionnaire. While the reliability test is testing the reliability of measuring instruments to find out the consistency of research instruments. Test reliability in this study with Cronbach's Alpha, the coefficient that describes how well the items in a set are positively correlated with each other. Reliability measurement based on Cronbach's Alpha $\alpha$ values. ${ }^{28}$

\footnotetext{
${ }^{24}$ Sugiyono, Metode penelitian Bisnis. (Bandung :Alfabeta ,2010),115.

${ }^{25}$ ibid, 116

${ }^{26}$ Sugiyono, Metode Penelitian Kuantitatif, Kualitatif Dan R\&D, 85

${ }^{27}$ Sugiyono, Metode Penelitian Kuantitatif, Kualitatif Dan R\&D, 39

${ }^{28}$ Saifuddin Azwar. Metode Penelitian. (Yogyakarta: Pustaka Pelajar, 2004),78
} 
The technique used for the validity test is done by Pearson productmoment correlation. If the value of $\mathrm{r}_{\text {count }}>\mathrm{r}_{\text {table }}$ means the item is declared valid. Meanwhile if the value of $r$ count $<r$ table means it is declared invalid. ${ }^{29}$ While the reliability test is carried out to measure a questionnaire which is an indicator of a variable or construct. The technique used for reliability testing is to use the Cronbach Alpha statistical test. A variable is said to be reliable if it gives a Cronbach Alpha value $>0.6$. And the data to be analyzed must pass the reliability test, because it is closely related to the results of the study.

Data Collection Technique

The instrument in this study, researchers used a questionnaire (questionnaire). The research instrument is a tool used by researchers to measure natural and social phenomena. ${ }^{30}$ In a questionnaire or questionnaire research, it will be used to multiply from the respondents, namely halal product entrepreneurs who have been in business for more than 10 years.

\section{Data Analysis Technique}

In this study, the data analysis technique used is the Factor Analysis (CFA / Confirmatory Factor Analysis) is a technique of factor analysis in which a priori based on the theories and concepts that are already known to be understood or predetermined, then made a number of factors that will be established, as well as what variables are included in each factor that forms and is definitely its purpose. Formation of a confirmatory factor (CFA) intentionally based on theories and concepts, in an effort to obtain new variables or factors that represent several items or sub-variables, which are observable variables or observational variables. ${ }^{31}$

\footnotetext{
${ }^{29}$ Imam, Ghozali. Aplikasi Analisis Multivariate Dengan Program IBM SPSS 21. (Edisi.Ke-7). (Semarang: Badan Penerbit Universitas Diponegoro,2013), 52

${ }^{30}$ Ibid, 103

${ }^{31}$ Imam Ghozali, 2006. Aplikasi Analisis Multivariate Dengan Program SPSS. Cetakan Keempat. (Semarang: Badan Penerbit Universitas Diponegoro), 49
} 
If $\mathrm{T}_{\text {arithmetic }}>\mathrm{T}_{\text {table, }}$ it is said to be significant

If $\mathrm{T}_{\text {arithmetic }}<\mathrm{T}_{\text {table, }}$ it is said to be insignificant

In this study, to analyze the factors that have an influence on marketing performance, researchers use the help of SPSS V16.0 software. Given the software is one software that can analyze factors, according to the needs of this research analysis.

\section{Results and Discussion}

Validity and Reliability Test

Validity of results of calculations using SPSS version 20 for windows, the result of validity test error rate is $5 \%$, of respondents 32 people, $r$ Table: As explained 0,349 valid if $r$ count $>r$ table $(0,349)$. For variable $Y$ with 5 item items, declared valid, variable $\mathrm{X}_{1}$ with 5 item items declared valid, $\mathrm{X}_{2}$ with 6 item items declared valid, $\mathrm{X}_{3}$ with 5 item items declared 2 invalid questions, while for $X_{4}$ and $X_{5}$ with 5 and 5 respectively. 7 item items declared valid. As for the reliability test, from the results of the test were obtained value of Cronbach alpha was 0.953 greater than the minimum value of Cronbach alpha, r 0.6 means that the questionnaire is reliable. These results indicate in an understanding that the instrument can be trusted enough to be used as a data collection tool, because the instrument is already good.

Adequacy of Sample Data and the Relationship between Factors

The results of the independent variable correlation test are in the KMO and Bartlett's Test output. KMO values indicate the adequacy of sample data and the existence of relationships between factors. The KMO and Bartlett's Test value for the desired correlation between variables is $>0.5$, which is indicated by the value of the Measure of sampling Adequacy (MSA). If there is a variable whose value is MSA $<0.5$, the process is repeated from the beginning by removing the variable whose value is MSA $<0.5$. The results of the KMO test in this study are shown in Figure 4.1 below, 
Figure 4.1KMO and Bartlett's Test

\begin{tabular}{|c|c|c|}
\hline \multicolumn{2}{|c|}{ Kaiser-Meyer-Olkin Measure of Sampling Adequacy. } & .809 \\
\hline \multirow[t]{3}{*}{ Bartlett's Test of Sphericity } & Approx. Chi-Squarel & 119.615 \\
\hline & df & 10 \\
\hline & Sig. & .000 \\
\hline
\end{tabular}

Source: Output SPSS for Windows 16

In the KMO and Bartlett Test tables above, the KMO Measure of Sampling Adequacy (MSA) figure is 0.809 . Because the value is 0.809 ('>0.5), it shows the adequacy of the sample. The KMO and Bartlet's test (without the chi-square value) is 119,615 with a significance value of 0,000 , indicating that there is a correlation between variables and is feasible for further processing. Based on the results of the MSA above, all independent variables can be further analyzed because each value is> 0.5 .

Factors Contributing to the Marketing Performance of Halal Products in Indonesia.

The factors that contribute to the marketing performance of halal products, as stated earlier, that based on the results of the analysis with CFA there are five independent variables that have contributed to the dependent variable, namely the marketing performance variable of halal products.

Contribution of Product Competition Variables.

Very high business competition climate makes it difficult for brand owners to develop and maintain products or services that are distinctive or unique, because it takes no small cost. Brand activation strategy - brand activation - is considered very appropriate for marketing products while still focusing on brand relationships with consumers. Therefore the competition of a halal product with other products will be able to influence the consumer's decision to buy the halal product. 
The results of statistical analysis obtained by researchers that the variable $\mathrm{X}_{2}$, namely the variable level of product competition with a correlation value of 0.920 , the results indicate a strong correlation, between the variable level of product competition with the marketing performance of halal products. So it can be said that the success of the marketing performance of halal products will be influenced by the level of competition of these products. To find out the relationship between product competition level variables and marketing performance, researchers asked six (6) question items developed based on indicators of product competition level variables.

The indicators of product competition used in this study are differentiation and diversification, product variation, good brand image, good quality and competitive prices. (i) Product differentiation and diversification is very necessary in winning a competition in the market, this is given that the needs of consumers run dynamically, therefore if a company wants to keep its products still exist and demanded by the market, then a product must have a difference value with other products. The difference in value of a product can also increase the level of customer satisfaction.

(ii) The second indicator of product competition is product variation and innovation. To be able to compete with other products, halal products must vary products and product innovations. The variety of characters and tastes of consumers requires a company to always innovate from its products, as well as variations that vary, for example is a food company, then variations of taste must be made to create customer satisfaction, if a product already has variations, it will be sought by consumers automatically. From the research results of Bharadwaj et al in 1993, that the company's ability to continue to innovate its products will keep the products in accordance with the wishes and needs of customers.

(iii) The third indicator of product competition is brand image. A good brand image on a product will cause a positive impression on consumers, with a positive impression from consumers of a product from the product brand, it will emerge the 
desire of consumers to buy the product. The halal product must be able to create a good brand image among the people so that it is easily known by the community and can compete with other products.

(iv) The fourth indicator is product quality. Good product quality will make it easier for companies to capture market share, especially if the product is sold to consumers who have high purchasing power, where consumers with high purchasing power will prioritize quality over a product.

(v) The fifth indicator of product competition is competitive prices. Creating halal products at affordable prices will be able to win the hearts of customers so they can master the market share, the price of a product is still a consideration for consumers in buying a product. So do not be surprised if we encounter several marketing strategies that feature in terms of the price of a product, where in general the price of a product is impressed as cheap as possible, it aims to attract the interest of consumers.

The results of this study reinforce the existing theories, that the level of product competition will increase the number of sales of a product. According to Song \& Parry there are three benchmarks to determine whether a company has a competitive advantage. First, the uniqueness of the product, which is the uniqueness of the company's products so that they can distinguish them from competing products or general products on the market. Second, product quality, namely the quality of the products that have been created by the company. And third, competitive prices, namely the ability of companies to produce products at prices that are able to compete in the market.

At the same time strengthening the results of previous research, among them is Endang Sutrasmawati's research in 2008. Endang Sutrasmawati research results in 2008 , showed that the development of product line strategies is one of the issues to expand the number of product lines in an effort to win a competition, namely 
describing a system relationship where the company can only exist and survive if it has unique advantages. The unique advantages can be done in a way; product differentiation and diversification, product variation and product innovation. ${ }^{32}$

Then the results of research from Abdul Raufu and Ahmad Naqiyuddin, in 2012 with the title People's Awareness on Halal Foods and Products: Potential Issues for PolicyMakers. The results of this study indicate that the main factors influencing Muslim awareness in consuming halal products are religious observance, product description, certification logos, and health reasons. The results of this study recommend to governments and policy makers to improve policy decisions and mechanisms to make Muslims in Malaysia more aware of halal food and products. Contributing Variables in HR Marketing Performance.

The excellence of a halal product is one of the factors that support the improvement of HR marketing performance, HR is one of the factors that must be considered by companies that want to develop their markets, this is because the business world runs dynamically, changes in steps must be in line with the acceleration, no company continues continuously offering the same goods / services can last a long time..$^{33}$ Marketing HR performance basically will affect the marketing performance of halal products, because HR Marketing is directly in contact with consumers or potential customers.

Statistical analysis results obtained by researchers that the variable $\mathrm{X}_{1}$ namely HR Marketing Performance variables that have a correlation value of 0.895 , the results of this analysis indicate a strong correlation between HR marketing performance with marketing performance of halal products, so it can be said the better performance of HR Marketing in marketing products, then the sales value of a product both in quantity and in monetary units will increase, and vice

\footnotetext{
${ }^{32}$ Endang Sutrasmawati, (2011). 96

${ }^{33}$ Hendro Tanoko, "Kontributor Kinerja Pemasaran Dari Aspek Reward, Individu Dan Kreatifitas Strategi Pemasaran.” JDM Jurnal Dinamika Manajemen, 1, No. 2, (2010), pp: 115-124.
} 
versa. Therefore companies basically will always be required to improve the quality of their human resources, including the HR market, which is the spearhead of marketing a product.

In this study five item questions were used to measure the effect of marketing HR performance on the marketing performance of halal products, which was developed through several indicators of marketing HR performance, while the indicators used included: (i) competent HR. A good HR recruitment will contribute well to marketing performance, in addition to increasing SMD competencies such as tiered training will improve the quality of HR owned by a company.

(ii) Employee Productivity, good employee productivity will create halal products that are more innovative than other products, while innovative products are judged to be able to meet consumer needs, thereby increasing sales value of halal products.

(iii) The third indicator is productivity growth, periodic productivity growth will improve the overall marketing performance of halal products, besides that employees who have no productivity value will only add to the financial burden of a company.

(iv) the last indicator to measure HR performance is employee motivation, if a person has motivation at work it will increase the productivity of the employee, so it is not surprising that many companies motivate their employees every day, motivation can be in the form of material or immaterial, material in general is in the form of certain bonuses when reaching a target set by the company, while motivation in the form of material generally takes the form of an "injection" of morale to all its employees.

The results of this study strengthen the theory of Human Capital, where Human capital is the most valuable asset in a company, especially its intellectual power. It is humans who regulate a company and who declare added value. In other words 
humans, especially their abilities, wisdom, or intellectual power have an important meaning and have a very big role in managing a company.

The results of this study are also in line with some of the previous studies, where improving the quality of human resources including compensation or rewards can improve work performance and motivate work, therefore company attention to rational and fair compensation or reward arrangements is urgently needed. If $\mathrm{HR}$ sees that compensation or reward is inadequate, their work performance, motivation and job satisfaction tend to decrease. Sarin research and Mahajan in 2001 made the hypothesis where compensation or reward coined a positive relationship to the performance of product development. The results of research from Sarin and Mahajan in 2001 also showed a positive relationship with speed on the market, innovation, and product quality. Janssen's research in 2011 as well as the perception of fairness in receiving compensation or reward for the effort made by a manager is someone who works hard because considering the income to be gained, someone gives most of their time and attention to the company and will feel valued, someone will be more invest all abilities for creativity to receive back what he has invested in the form of compensation or reward, and the compensation or reward he receives will be in line with the creativity or contribution that will be given to the company.

\section{Contribution of Infrastructure Variables}

The infrastructure referred to in this study is soft and hard infrastructure or physical and non-physical infrastructure. Infrastructure both physical and nonphysical (government regulations) can affect a company's marketing performance, this is based on the Structure-Behavior and Performance (SCP) paradigm in the industry, that all SCP components are influenced by government policies in the form of direct intervention on various components in the SCP as well as coloring the 
business environment in which the industry operates. ${ }^{34}$ Forms of government policy can be in the form of laws or government regulations (PP) and other regulations.

Infrastructure development is one of the important and vital aspects to accelerate the national development process. Infrastructure also plays an important role as one of the drivers of economic growth. This is because the rate of movement and economic growth of a country cannot be separated from the availability of infrastructure such as transportation, telecommunications, sanitation, and energy. Therefore, the development of this sector becomes the foundation of further economic development.

The results of this study indicate that the third variable that has a contribution to the marketing performance of halal products is the $\mathrm{X}_{5}$ variable namely Infrastructure variable with a correlation value of 0.873 , these results indicate a strong relationship between infrastructure and marketing performance of halal products. With soft infrastructure, entrepreneurs will get legal certainty in entrepreneurship, while rough infrastructure will make it easier for business people to reach the market. So that it will be able to increase the ability of business actors to increase sales.

In this study 6 question items were used to measure the contribution of infrastructure to the marketing performance of halal products, which researchers developed from several key indicators. The indicators of infrastructure variables include: (i) Facilities and Infrastructure. The government policy in the form of a law on halal products is very influential in the development of the halal product industry in Indonesia. Good infrastructure is needed to develop marketing performance, infrastructure in terms of rough infrastructure, in the context of the economy as a terminology of umbrella in which many activities related to "social overhead

${ }^{34}$ Carlton, Dennis W., and Jeffrey M. Perloff. Modern Industrial Organization, Thirded. AddisonWesley, 2000. 
capital ".Better much " social overhead capital " is viewed as the foundation for improved living standards, better national land use and sustainable economic growth.

(ii) Government policies. The government policy in the form of a law on halal products is very influential in the development of the halal product industry in Indonesia. The government as the legal authority has the right to make a rule that is binding to anyone who is in the administrative area of a government. So basically the government can help develop halal products through policies aimed at developing halal products, in certain areas. Government policies are basically not only limited to the making of laws and regulations, but more broadly for example is to create an institution that guarantees halal products, to ensure that halal products sold in the market are truly halal both from the way of production to distribution. The existence of a halal product guarantor institution claps the government makes it easy for us to choose halal products.

Then the third indicator (iii) Halal attribute. Every halal product must be accompanied by halal attributes in the form of a halal logo and halal certification on the packaging, as a sign that the product has been certified by an authorized institution, without the logo on the package it will cause a negative impression from consumers or potential customers, so that official government regulations are expected to ensure the halal certainty of the product, and the element of goodness (thoyiban) of the product. The halality and goodness of a product is not only symbolic that the product is suitable for consumption, but the halal and thoyib labels are symbols of the benefits and hygiene of the product, this is what makes non-Muslim citizens also consume halal products.

In the context of the statement above, it can be seen how infrastructure has a broad role and is considered as a driver in economic growth. Its role in developing an area is undoubtedly clear, so some empirical facts state that the development of 
infrastructure capacity in an area will go hand in hand with the development of economic output Infrastructure also has an important influence on improving the quality of life and human welfare, among others in increasing the value of consumption, increasing labor productivity and access to employment, as well as increasing real prosperity and the realization of macroeconomic stabilization, namely fiscal sustainability, the development of credit markets, and its influence on the labor market.

The results are consistent with the results of the analysis of BI (Bank Indonesia) by Growth Diagnostic approach clearly and firmly already portray the problems and challenges that must be faced by Indonesia's economic growth, the result of the growth diagnostic indicates the development of infrastructure remains a constraint to economic growth in Indonesia, particularly related to inter-regional connectivity. Issues such as the need for high-capacity and high-quality ports, airports, roads and railways are considered to still trigger high logistics costs. Export and import-oriented manufacturing industry activities clearly still require a more viable port, including on Java as the biggest contributor to the national economy.

Contributions Amount of Distribution Cost Variable

The results of this study indicate that the fourth variable that has a contribution to the performance of halal product marketing is the $\mathrm{X}_{4}$ variable, namely the Distribution Cost Magnitude variable with a correlation value of 0.741 and the results show a strong correlation between the distribution costs and the marketing performance of halal products in Indonesia. In measuring this variable the researchers used 7 question items developed based on several indicators of the distribution cost variable. The indicators that researchers use are sales volume, location and number of customers.

If the level of competition between producers of halal products is getting tougher, then the distribution costs incurred will also be a lot. Many small sales 
volume of halal products will affect the distribution costs, then the amount of trading partners will affect the size of the sales volume of halal products so that it impacts on the distribution costs incurred and the large number of customers will generate a large profit so that distribution costs will be covered by profits earned $h$.

The results of this study reinforce the research of Abdullah, et al in a study conducted in Malaysia showing that the distance between trading partners affects the number of sales of halal products, where the closer the distance between the two the higher the number of halal products sold, and vice versa the further the distance the two except the number of halal products sold. ${ }^{35}$ In this case it can be said that distribution costs also have an influence on marketing performance, this is given that one measure of marketing performance is the volume or value of product sales.

Contribution of Market Competition Level Variable

The results of this study indicate that the variable $\mathrm{X}_{3}$ namely the variable Market Competition with a correlation value of 0.572 . Which shows that market competition also has a strong correlation with the marketing performance of halal products. These results indicate that companies are required to always increase their competition with other competitors. Business competition is not always carried out with fair competition, there are several companies in seizing the share market in unhealthy ways, therefore the government as the legal authority must be able to create a climate of healthy competition among business actors, one of which can be done with the application of regulations legislation or other government regulations governing competition between businesses, for the creation of sustainable economic growth.

Many countries make laws and laws to maintain market competition and prevent anti-competitive practices or unfair business competition. For example, in

\footnotetext{
${ }^{35}$ Abdullah, dkk. A Review of Malaysia's Halal Trade Performance: Does Distance and Muslim Population Plays a Difference? In Proceedings of 47th International Business Research Conference13, (2017)
} 
Indonesia there is a Business Competition Supervisory Commission mandated by law, and in the United States there are various laws called antitrust law. ${ }^{36}$ Regarding halal products, several countries have also implemented regulations for halal products, from the production process to distribution to consumers. Like for example in Indonesia to protect consumers from products circulating in the market to avoid illicit products, the government is working with MUI (The Indonesian Council of Ulama) to certify halal products to every company that circulates halal products.

The results support previous research carried out by Muhammad Nusron, et al in 2015 under the title Policy Halal Products with Dynamic System Simulation to Increase Number of Halal certified products. Muslim consumers in Indonesia are very sensitive to the food consumed. While a Halal specification has become a global trend and the needs of the world community. The aim of this research is to create a policy of halal products through a Dynamic System simulation to see trends in the number of halalcertified products. Data is processed using Ventura Simulator (Vensim). After the Simulation Model Design, Validation and Verification Model stages, a Halal Certification Simulation Model is obtained. In the Halal Certification Process Submodel using CEROL SS-23000 takes only 40 days, 55.6 percent faster than the previous 90 days.

One of the theories of the trade, which is quite well known is the theory of competitive advantage, led by Michael Porter is essentially that in this era of global competition, the country would be able to compete if it has a dominant factors such as factor and demand conditions, related and supporting industry, and firm strategy structure and rivalry. In fact, lately there has been a tendency for competitive liberalization to emerge, which is a combination of implementing a dynamic comparative advantage theory with a competitive advantage theory. On the other hand, an increasingly open trade policy as applied by Indonesia today has

\footnotetext{
${ }^{36}$ Mark Blaug, 2008. "Invisible Hand," The New Palgrave Dictionary of Economics, 2nd Edition, v. 4, (New York: Pelgrave MacMilan, 2008), 565
} 
increased the risk of external shocks to the domestic economy, especially on the development of halal products in circulation in Indonesia.

Thus the product or food is produced in accordance with halal recipes that can be accepted by Muslim consumers and consumers of other religions. For Muslim consumers, halal food and drink means that the product meets the requirements stipulated by sharia law while for non-Muslim consumers, it represents a symbol of cleanliness, quality and safety of the product when it is produced strictly under the Holistic Halal Assurance Management System. Therefore, consumers are very caring and are always aware of what they eat, drink and use in meeting their daily needs. Marketing Performance Factors that Have the Most Dominant Multiplier Effect on the Development of Halal Products in Indonesia.

As the second objective of this research is to find out and analyze the marketing performance factors that have the most dominant multiplier effect on the development of halal products in Indonesia, based on the results of the analysis using the CFA method and literature review, this discussion will be based on CFA analysis and several theories and previous research. As follows. Of the several marketing performance factors formed through literature review and after analysis using the CFA method, namely HR Marketing Performance variables, Product Competition Variables, Distribution Cost Variables Variables, Infrastructure Variables and Market Competition Level Variables, then the product competition variables are variables that can has a correlation value of 0.920 . This matrix of component values shows a strong correlation between product competition variables and marketing performance of halal products. The correlation value is greater than the other four independent variables. So it can be said that the product competition variable has the most dominant multiplier effect in the development of halal products.

In this study, researchers used 7 question items to measure the marketing performance of halal products that researchers developed from several marketing 
performance indicators. These indicators are the volume of sales, the number of customers, profits, sales growth and the number of competitors, where these indicators from the results of the literature review can describe the quality of marketing performance including the marketing performance of halal products.

First, the first indicator is sales volume. The sales volume can be the quantity of halal products sold, or the monetary unit. When a product has a high level of competition compared to other similar products, it will attract consumers or potential customers or even be able to maintain customer loyalty. The level of product competition cannot be built in a short time, therefore companies need planning in shaping the level of product competition, both from quality, competitive prices or appearance that can attract consumer interest. The hallmark of a company's sales success can be seen through how the level of sales of the company's products and services, because the marketing strategy is always aimed at increasing the number of sales.

Second, the second indicator is the number of customers, the success of marketing performance can be seen how much the market share achieved by the company can be seen from the existing market potential. If the quantity of customers is small, it can be said that marketing performance is lacking or unsuccessful. Basically, the number of customers is also closely related to the increase in sales of halal products, which shows an increase in the number of customers of existing halal products. Companies both goods and services in general will always strive so that the number of customers always increase from time to time, the number of customers illustrates the existence of the company.

Third, the third indicator of marketing performance is the profit gained by the company. Sales volume and number of customers can describe the amount of profits to be gained by a company, where all three are positively related if the sales volume and the number of customers increases, the company's profits will also increase. That 
way the company will easily expand its market share. Furthermore, the results of the component matrix can be further analyzed based on theoretical studies and previous research, which variables have the biggest contribution to the marketing performance of halal products and variables that have a multiplier effect on the development of halal products in Indonesia. Therefore, one of the efforts that can be made by companies that produce halal products is by increasing the level of competition for products sold in the market.

\section{Conclusion}

From the results of the discussion above, two main conclusions can be drawn, namely: First, the factors that contribute to the marketing performance of halal products, based on the analysis of the CFA method there are five independent variables that have a contribution to the dependent variable, namely the performance variable marketing of halal products, namely: 1) Product Competition Variable, with a correlation value of 0.920. 2) HR Marketing Performance Variable, with a correlation value of 0.895. 3) Infrastructure Variables, with a correlation value of 0.873 . 4). Magnitude Distribution Fees Variable, the correlation value of 0.741 . And 5) Level of Market Competition Variable, the correlation value of 0.572. Second, from several marketing performance factors formed through literature review and after analysis using the CFA method. Product competition variable is a variable that has a correlation value of 0.920 . This matrix of component values shows a strong correlation between product competition variables and marketing performance of halal products. The correlation value is greater than the other four independent variables. So it can be said that the product competition variable has the most dominant multiplier effect in the development of halal products.

\section{References}


Abdullah, et al. A Review of Malaysia's Halal Trade Performance: Does Distance and Muslim Population Plays a Difference?. Proceedings of the 47th International Business Research Conference 13-14 December 2017, Hyatt Regency, Osaka, Japan

Afroniyati, Lies. The Political Economy Analysis of Halal Certification by the Indonesian Ulema Council. Journal of Policy \& Public Administration (JKAP) Vol. 18, No. 1, May 2014

Ali Rama, "The Potential Market of Halal World Products," Fajar, 2014, https://www.academia.edu/10449487/P Potential_Pasar_Pasar_Paluk_Halal_Dunia.

Ariffin, Adilah. Factors That Affect the Demand for Halal Cosmetic Products. Proceedings of the Tamadun \& Islamic Heritage Nationality Seminar (TAWIS). 2016. 18-30.

Bakar, Norlaila Abu Idris, and Nor Aini Haji. The Importance of Exporting Halal Food Products among PKS Entrepreneurs in Malaysia http://www.ukm.my/hairun/kertas\%20kerja\%20iCEPs/Keupayaan\% 20 Exporting\%20Products\%20Food\%20Halal.pdf

Darsono et al. The dynamics of Islamic financial products and contracts in Indonesia. Jakarta: Bank Indonesia Central Banking Research Department. 2016

Ferdinand. Management Research Methods: Research guidelines for Thesis, Thesis, and Desertation. Management Science, Semarang: Diponegoro University Publisher Agency. 2000

Idris, Nor Aini Haji and Noor, Modh Ali Mohd. Analysis of Muslim User Concerns About the Halal-Haram Issue of Products Through Index Formation. PROCEEDING OF PERKEM VIII, Volume 3 (2013) 1245 - 12 ISSN: 2231-962X. VIII's Malaysian Economic Nationality Trial (PERKEM VIII) "Basic Lay in the Era of Economic Transformation: Cabaran and Halatuju" Johor Bahru, 7 - 9 Jun 2013

Indonesian Ministry of Trade. Market Intelligence: Halal Food Products, Indonesian Handicrafts and Furniture in the Japanese Market, Tokyo.2015 Trade Attache.

Karim, A. Adiwarman. Islamic Microeconomics, Third Edition. Jakarta: PT Raja Grafindo Persada.2010.

Ma'ruf Amin, Islamic Legal Solution (Makharij Fighiyah) As a New Islamic Shariah Current Driver in Indonesia (DSN-MUI Fatwa Contribution in Indonesian Laws and Regulations). SCIENTIFIC ORGANIZATION Presented in Inauguration of Professor of 
Muamalat Syariah Economics. Ministry of Religion of UIN Maulana Malik Ibrahim Malang. 2017

Mudiantono and Khamidah, Nur. Effect of Product Diversification on Marketing Performance at PT Bank Mandiri (Persero) Tbk Kanwil X Makassar, MINDS: Journal of Management and Inspiration, Vol. 3, No. 1. Year 2016. http://journal.uinalauddin.ac.id/index.php/minds/article/view/4619/4205, accessed on 15 October 2018

Mudiantono and Khamidah, Nur. Analysis of the Influence of Environmental Factors on Product Innovation and Creativity in Marketing Strategies in Improving Marketing Performance (Study on Ceramic Craft Companies in Kasongan Center, Bantul Regency, Yogyakarta), Journal of Business and Economics, Vol. 12, No. 1, 2005

Muhammad Nusron, et al. Halal Product Policy with Dynamic System Simulation to Increase the Number of Halal Certified Products . PROSIDING OF NATIONAL SEMINAR OF INDUSTRIAL TECHNOLOGY III 2015 ISBN: 978-602-14822-2-3.

News Export Business Opportunities for Halal Products in Great France Thanks to Muslim Population Growth Edition: DGNED / MJL / 004/4/2013. April 2013

Nurohman, dede. The Concepts of Self Interest and Maslahah in Islamic Economic Rationality. Islamica: Journal of Islamic Studies. Vol. 5, No. September 1. 2010.

OJK (Financial Services Authority), 2017-2019 Indonesian Sharia Financial Development Roadmap.

Rafki, Ahmad. Determinants on the Obtainment of Halal Certification Among Small Firms. World Applied Sciences Journal 32 (1): 47-55, 2014.

Rahwati, Rahmi. Development and Outlook of the Halal Industry. Extracted from the 2014 Sharia Economic Outlook Book - Sharia Economic Society (MES).

Republic of Indonesia Law Number. 34 of 2014 concerning Halal Product Guarantee (JPH).

Saifuddin, Azwar. Research Method. Yogyakarta: Student Library. 2004.

Santoso, Singgih. Series of IT-Based Business Solutions: Using SPSS for Multivariate Statistics. Jakarta: Elex Media Komputindo, 2006

Shinta, Agustina. Marketing Management, Malang: Universitas Brawijaya Press (U B Press). 2011 
Jurnal Hunafa: Studia Islamika, Volume 16, Number 1, p. 111-141.

E-ISSN: 2355-7710

P-ISSN: $1411-125 \mathrm{X}$

Sugiyono Quantitative, Qualitative, and R\&D Research Methods. Bandung: ALFABETA, 2012

Sutrasmawati, Endang. Effect of Product Competition in Improving Marketing Performance through Competitive Advantage. Journal of Business and Economics (JBE), Vol. 15, No.2, September 2008. Pg, 91-97.

Tanjung, H and Devi, A. 2013. Islamic Economic Research Methods. Jakarta: Gramata Publishing

Yunos, et al. Understanding Mechanisms to Promote Halal Industry the Stakeholders' Views. Procedia - Social and Behavioral Sciences 130 (2014) 160 - 166. https://www.sciencedirect.com/science/article/pii/S1877042814029309. Acce ssed April 29, 2018 